\title{
PENERAPAN MODEL PEMBELAJARAN STUDENT TEAM ACHIEVEMENT DIVISIONS (STAD) DAN NUMBER HEAD TOGETHER (NHT) TERHADAP HASIL BELAJAR SISWA
}

\author{
Neni Murniati ${ }^{*}$, Ance Villa Lestari² ${ }^{2}$ Irwandi $^{3}$ \\ ${ }^{1}$ Program Studi Pendidikan Biologi, Fakultas Keguruan dan Ilmu Pendidikan, Universitas Bengkulu \\ ${ }^{2,3}$ Program Studi Pendidikan Biologi, Fakultas Keguruan dan Ilmu Pendidikan Universitas Muhammadiyah \\ Bengkulu \\ email: nenimurniati@unib.ac.id
}

\begin{abstract}
Abstrak
Penelitian ini bertujuan untuk mengetahui perbedaan hasil belajar siswa pada pembelajaran biologi dengan menggunakan model pembelajaran Student Team Achievement Divisions (STAD) dan Number Head Together (NHT) pada kelas yang berbeda SMPN 3 Kota Bengkulu. Penelitian ini dilakukan dengan metode Kausal Komparatif. Design penelitian ini menggunakan design Nonequivalen Control Group Design. Sampel dalam penelitian ini adalah siswa kelas VIII yang diambil 2 kelas yang ditetapkan secara acak (random sampling). Kelas pertama dengan menggunakan pembelajaran STAD dan kelas kedua dengan NHT. Pengumpulan data penelitian menggunakan instrumen berupa soal kemampuan hasil belajar kognitif. Analisis data menggunakan Uji t (uji hipotesis). Data hasil penelitian menunjukkan bahwa rata-rata hasil belajar biologi siswa menggunakan model pembelajaran STAD $(84,44)$ lebih tinggi dibandingkan nilai rata-rata hasil belajar siswa menggunakan model NHT $(78,51)$ dengan selisih sebesar 9,93.
\end{abstract}

Kata kunci: Hasil belajar, model pembelajaran,STAD, NHT

\begin{abstract}
This study aims to determine differences in student learning outcomes in biology learning by using Student Team Achievement Divisions (STAD) and Number Head Together (NHT) learning models in different classes of state junior high school number 3 Bengkulu City. This research was conducted by the Comparative Causal method. The design of this study uses the Nonequivalent Control Group Design. The sample in this study was grade VIII students who were taken 2 classes that were randomly assigned. The first class using STAD learning and the second class with NHT. Research data collection using an instrument in the form of a cognitive learning achievement problem. Data analysis using $t$ test (hypothesis test). The results of the study showed that the average student biology learning outcomes using the STAD learning model (84.44) were higher than the average value of student learning outcomes using the NHT model (78.51) with a difference of 9.93
\end{abstract}

Keywords: Learning outcomes, learning models, STAD, NHT 


\section{PENDAHULUAN}

Pendidikan memegang peran yang sangat penting, karena pendidikan merupakan wahana untuk meningkatkan dan mengembangkan kualitas sumber daya manusia suatu bangsa. Pembaharuan pendidikan harus selalu dilakukan untuk meningkatkan kualitas pendidikan nasional (Perano, 2009). Proses pendidikan tak dapat dipisahkan dengan upaya untuk mengembangkan sumber daya manusia yang berkualitas. Manusia yang berkualitas itu dilihat dari segi pendidikan yang telah terkandung secara jelas dalam tujuan pendidikan nasional.

Pendidikan merupakan usaha sadar dan terencana untuk mewujudkan suasana belajar dan proses pembelajaran agar peserta didik secara aktif yang dapat mengembangkan potensidi dalam dirinya. Pendidikan yang lebih menitikberatkan pada sebuah proses mengeksplorasi bakatbakat individu secara alamiah yang dimiliki sejak lahir. Potensi-potensi inilah yang jika diberdayakan akan membekali seseorang untuk hidup lebih mengerti tentang hal-hal yang ada disekitarnya, sehingga pendidikan diharapkan bias memaksimalkan potensi-potensi ini yang akan membekali manusia dalam interaksinya dengan yang di luardirinya (Latif,2007). Hasil pendidikan nantinya dapat memiliki kekuatan spiritual, keagamaan, pengendalian diri, kecerdasan, ahlak mulia, serta keterampilan yang diperlukan dirinya dan masyarakat.

Pembelajaran adalah kegiatan yang dilakukan guru sehingga tingkah laku siswa berubah kearah yang lebih baik. Pembelajaran adalah upayaguru menciptakan iklim dan pelayanan terhadap kemampuan, potensi, minat, bakat, dan kebutuhan siswa yang amat beragam agar terjadi interaksi optimal antara guru dan siswa serta antar siswa (Hamdani, 2011). Berbagai upaya telah dilakukan untuk meningkatkan mutu pendidikan di sekolah, antara lain dengan perbaikan mutu belajar mengajar. Namun permasalahan masih selalu timbul yaitu permasalahan atau hambatan yang berkaitan dengan proses pembelajaran dapat disebabkan oleh beberapa komponen. Komponen-komponen pembelajaran tersebut adalah kemampuan guru dalam pengajaran, pihak yang diberi materi pembelajaran (siswa), bahan yang diajarkan (bahan ajar), proses pembelajaran (pendekatan, strategi, metode, teknik mengajar), sarana dan prasarana belajar, serta sistem evaluasi yang diterapkan. Masing-masing komponen tersebut saling mempengaruhi dalam upaya pencapaian tujuan pembelajaran (Suryosubroto, 2009)

Sekolah sebagai suatu lembaga pendidikan formal, secara sistematis merencanakan bermacam-macam lingkungan, yakni lingkungan pendidikan yang menyediakan berbagai kesempatan bagi siswa untuk melakukan kegiatan belajar. Melalui berbagai kesempatan belajar itu, pertumbuhan dan perkembangan siswa diarahkan dan didorong kepadapencapaian tujuan yang dicita - citakan. Lingkungan tersebut disusun dan ditata dalam suatu kurikulum, yang pada gilirannya dilaksanakan dalam bentuk proses pembelajaran (Hamalik, 2008). Pencapaian tujuan pembelajaran ini, setiap guru dituntut untuk benar-benar memahami model dan pembelajaran yang akan di terapkan, sehubungan dengan hal tersebut,seorang guru perlu memikirkan model dan media yang akan digunakan, pemilihan dan metode dan media pembelajaran yang tepat akan berdampak pada aktivitas dan tingkat penguasaan dan prestasi belajar peserta didik. 
Namun faktanya di lapangan guru masih kurang menggunakan model pembelajaran pada saat proses pembelajaran di kelas dikelas. Hasil observasi yang telah dilakukan pada Sekolah Menengah Pertama Negeri 3 yaitu, pada pelaksanaan kegiatan belajar mengajar sebelumnya guru hanya menggunakan metode ceramah dan penugasan biasa saja sehingga hasil belajar siswa masih belum memenuhi standar yaitu rata-rata 6,5. sedangkan standar ketuntasan belajar pada mata pelajaran IPA yang ditetapkan sekolah adalah apabila siswa mencapai nilai 75 keatas sebesar $85 \%$. Dan juga sebagai masukan untuk guru IPA di SMP N 03 Kota Bengkulu untuk lebih kreatif dalam memilih strategi pembelajaran agar pembelajaran tersebut lebih menarik dan siswa lebih aktif.

Peran pengelolaan pembelajaran dalam usaha mencapai tujuan pembelajaran sangat penting, yaitu untuk mengetahui pengetahuan awal siswa sebelum pembelajaran dimulai, maka dilakukan penelitian khususnya untuk mengetahuai perbedaan hasil belajar siswa, salah satunya menggunakan Pembelajaran Kooperatif Tipe Student Team Achievement Divisions (STAD) dan Number Head Together (NHT). STAD merupakan salah satu tipe model pembelajaran kooperatif yang menempatkan siswa dalam tim yang beranggotakan kurang lebih 4 orang yang merupakan campuran menurut tingkat prestasi, jenis kelamin dan suku. Guru menyajikan pelajaran, kemudian siswa bekerja didalam tim untuk memastikan bahwa seluruh anggota tim telah menguasai materi tersebut. Komponen utama dalam model STAD terdiri dari 1) Penyajian kelas, 2) Penetapan siswa dalam kelompok, 3) Tes dan Kuis, 4) Skor pengembangan dan 5) Penghargaan kelompok (Slavin, 2008). NHT atau penomoran berpikir bersama adalah merupakan jenis pembelajaran koperatif yang dirancang untuk mempengaruhi pola interaksi siswa dan sebagai alternatif terhadap struktur kelas tradisional. Langkah-langkah NHT adalah 1) penomoran; 2) pengajuan pertanyaan, 3) berpikir bersama, dan 4) pemberian jawaban (NHT) adalah pendekatan yang dikembangkan oleh Spencer Kagan (1998) untuk melibatkan lebih banyak siswa dalam review berbagai materi yang dibahas dalam sebuah pelajaran dan untuk memeriksa pemahaman mereka tentang isi pelajaran itu (Arends, 2008).

Berdasarkan dari permasalahan tersebut, menggunakan suatu modell pembelajaran dalam langkah persiapan pembelajaran dengan harapan mampu mengatasi kendala-kendala yang terjadi. Pembelajaran yang diarahkan adalah Pendekatan dengan harapan Pembelajaran IPA biologi di SMPakanmampu meningkatkan hasil belajar siswa. Mengacu pada permasalahan di atas, maka tujuan penelitian ini mengetahui perbedaan hasil belajar siswa yang menggunakan model STAD dan NHT.

\section{Metode Penelitian}

Metode penelitian ini menggunakan metode Kausal Komparatif yaitu penelitian yang dilakukan untuk membandingkan variabel model pembelajaran antara STAD dan NHT terhadap hasil belajar siswa. Design penelitian yang digunakan adalah Nonequivalen Control Group Design dibagi dalam 2 kelompok yaitu kelas pertama diberi pembelajaran antara STAD dan NHT. Penelitian ini dilaksanakan di kelas VIII (delapan) SMPN 03 Kota Bengkulu untuk menguji hipotesis dengan rancangan penelitian dimana kedua sampel diberi perlakuan yang berbeda. teknik 
pengumpulan data yang dilakukan sebanyak 2 kali yaitu pengambilan data hasil belajar siswa yang dilakukan sebelum (pretest) dan sesudah (postest )siswa mengikuti pembelajran menggunakan model STAD dan NHT di SMPN 03 kota bemgkulu. Instrumen dalam penelitian ini meliputi intrumen pembelajaran yaitu: Silabus, RPP, Lembar Diskusi Siswa (LDS), dan instrumen pengumpulan data untuk mengetahui hasil belajar kognitif siswa.. Analisis data yang digunakan yaitu dengan uji t. Pproses pengolahan datanya dengan menggunakan SPSS 19.0, sebelum melakukan uji terlebih dahulu akan dilakukan uji prasyarat yaitu uji normalitas dan uji homogenitas varian.

\section{Hasil dan Pembahasan}

Dari data nilai hasil skor tes pada pembelajaran yang menggunakan model pembelajaran kooperatif STAD dan NHT diperoleh nilai rata-rata hasil skor tes pada kelas VIII 3 pembelajaran yang menggunakan model pembelajaran kooperatif tipe NHT dan VIII 4 model pembelajaran kooperatif tipe STAD dapat disajikan pada tabel dibawah ini.

Tabel 1: Perhitungan Skor Hasil Belajar Siswa Berdasarkan Tes Awal (Pre-test)

\begin{tabular}{ccc}
\hline \multirow{2}{*}{ Perhitungan } & \multicolumn{2}{c}{ Kelas } \\
\cline { 2 - 3 } & STAD & NHT \\
\hline Jumlah skor & 1510 & 1350 \\
Skor tertinggi & 90 & 80 \\
Skor terendah & 10 & 20 \\
Rata-rata & 55,92 & 52,22 \\
\hline
\end{tabular}

Berdasarkan hasil penelitian yang telah dilakukan terhadap kegiatan belajar mengajar biologi kelas VIII 4 dan VIII 3 pada pokok bahasan sistem indra penglihatan pada manusia. Pada kelas yang menggunakan model pembelajaran tipe STAD sebelum perlakuan dilakukan pengukuran awal (pre-test) terlebih dahulu. Hasil pengukuran ini rata-rata hasil pre-test siswa STAD yakni 55,92 sedangkan untuk kelas NHT nilai rata-rata hasil belajar siswa yakni 52,22

Sebelum melakukan uji $\mathrm{t}$ harus periksa terlebih dahulu uji normalitas dan uji homogenitas varian, uji normalitas data skor pretest hasil belajar siswa menggunakan uji sampel kolmogorov- smirnov, berikut hasil rekapitulasi perhitungan hasil belajar siswa pada sub pokok sistem indra penglihatan pada manusia pada kelas STAD dan NHT.

1)Uji normalitas nilai pre-test

Uji normalitas nilai pre-test pada pembelajaran STAD dan NHT dapat dilihat pada tabel dibawah ini, uji normalitas data skor pre-test kemampuan siswa menggunakan uji sampel kolmogorovsmirnov dengan sig yang lebih diatas 0,05 maka data skor pretest berdistribusi normal, tabel dibawah ini merupakan rekapitulasi kemampuan awal pada kelas yang menggunakan model STAD dan NHT. 
Tabel 2. Uji Normalitas Skor Pre-Test Pada Kelas Yang Menggunakan Model pembelajaran kooperatif tipe STAD dan NHT

\begin{tabular}{llllrl}
\hline \multirow{2}{*}{ Model Pembelajaran } & \multicolumn{3}{c}{ Kolmogorov-Smirnov $^{\text {a }}$} \\
\cline { 3 - 6 } & & $\begin{array}{c}\text { Statist } \\
\text { ic }\end{array}$ & df & Sig. \\
\hline Nilai Pre & STAD &, 125 & 27 & $200^{*}$ \\
Test & NHT &, 165 & 27 & &, 056 \\
\hline
\end{tabular}

Berdasarkan tabel di atas menunjukkan bahwa nilai pretest kemampuan awal siswa pada sub pokok sistem indra penglihatan pada manusia pada kelas STAD dan NHT berdistribusi normal, setelah diketahui normalitas data dilanjutkan dengan uji homogenitas varian, dengan menggunakan uji levana, hasil uji homogenitas varian adalah sebagai berikut:

2). Uji Homogenitas nilai pre-test

Tabel 3. Uji Homogenitas Nilai Pre-Test Pada Kedua Sampel Yaitu Dengan Model Pembelajaran Kooperatif Tipe STAD dan NHT

\begin{tabular}{rrrr}
\hline Nilai Pre Test & & \multicolumn{2}{c}{ Test of Homogeneity of Variances } \\
\hline $\begin{array}{cccc}\text { Levene } \\
\text { Statistic }\end{array}$ & df1 & df2 & Sig. \\
\hline, 154 & 1 & 52 &, 696 \\
\hline
\end{tabular}

Uji homogenitas nilai pre-test pada kedua sampel yaitu dengan pembelajaran STAD dan NHT dapat dilihat pada tabel diatas, dan dari tabel diatas dilihat signifikansinya lebih dari 0,05 sehingga kita ketahui bahwa data pretest kemampuan awal siswa yang menggunakan model pembelajaran STAD dan NHT mempunyai varians yang homogen.

3). Uji kemampuan awal
Setelah diketahui bahwa data pretest hasil belajar siswa ini berdistribusi normal dan homogen maka untuk melihat perbandingan perbedaan hasil belajar awal siswa dari kedua kelas maka dilakukan uji $t$ yang hasilnya sebagai berikut:

4). Menghitung nilai uji t atau uji hipotesis hasil belajar awal siswa

Tabel 4. Nilai uji t

$$
\text { Independent Samples Test }
$$




\begin{tabular}{|c|c|c|c|c|c|c|c|c|c|c|}
\hline & & \multirow[t]{2}{*}{$F$} & \multirow[t]{2}{*}{ Sig. } & \multirow[t]{2}{*}{$T$} & \multirow[t]{2}{*}{$d f$} & \multirow{2}{*}{$\begin{array}{l}\text { Sig. } \\
(2- \\
\text { taile } \\
\text { d) } \\
\end{array}$} & \multirow[t]{2}{*}{$\begin{array}{l}\text { Mean } \\
\text { Differe } \\
\text { nce }\end{array}$} & \multirow[t]{2}{*}{$\begin{array}{c}\text { Std. Error } \\
\text { Differenc } \\
\text { e }\end{array}$} & \multicolumn{2}{|c|}{$\begin{array}{l}\text { 95\% Confidence } \\
\text { Interval of the } \\
\text { Difference }\end{array}$} \\
\hline & & & & & & & & & Lower & Upper \\
\hline \multirow{2}{*}{$\begin{array}{l}\text { Nilai Pre } \\
\text { Tes }\end{array}$} & $\begin{array}{l}\text { Equal } \\
\text { variances } \\
\text { assumed }\end{array}$ & 154 & 696 & 706 & 52 & ,483 & $\begin{array}{r}3,7037 \\
0\end{array}$ & 5,24588 & $-6,82292$ & 14,23033 \\
\hline & $\begin{array}{l}\text { Equal } \\
\text { variances } \\
\text { not } \\
\text { assumed }\end{array}$ & & & 706 & $\begin{array}{r}51,65 \\
2\end{array}$ & ,483 & $\begin{array}{r}3,7037 \\
0\end{array}$ & 5,24588 & $-6,82461$ & 14,23202 \\
\hline
\end{tabular}

\section{Hipotesis nilai pretest}

Ho $: \mu 1=\mu 2$ (tidak ada perbedaan yang signifikan hasil belajar biologi Siswa antara yangmenggunakan model pembelajaran Kooperatif tipe STAD dan yang menggunakan Model pembelajaran NHT) Ho : $\mu 1 \neq \mu 2$ (ada perbedaan yang signifikan antara hasil belajar siswa Yang Menggunakan model pembelajaran kooperatif tipe STAD dan yang menggunakan model NHT pada mata Pelajaran biologi).

Dilihat dari tabel uji t di atas bahwa hasil belajar antara kedua kelas memiliki perbedaan nyata, dari data-data nilai diketahui bahwa kemampuan siswa untuk skor STAD yakni 55,92 lebih tinggi dibandingkan model pembelajaran NHT yang nilainya hanya 52,22 (lampiran 8 dan 9). Sehingga dapat disimpulkan bahwa pembelajaran yang menggunakan model STAD dapat meningkatkan hasil kemampuan belajar siswa dibandingkan dengan pembelajaran yang menggunakan model NHT.

2. Post-test hasil belajar siswa Data posttest hasil belajar siswa dapat dilihat pada ringkasan data tabel dibawah ini.

Tabel 5. Perhitungan Skor Hasil Belajar Siswa Berdasarkan Tes Akhir (Postest)

\begin{tabular}{ccc}
\hline Perhitungan & \multicolumn{2}{c}{ Kelas } \\
\cline { 2 - 3 } & STAD & NHT \\
\hline Jumlah skor & 2310 & 2090 \\
Skor tertinggi & 100 & 100 \\
Skor terendah & 70 & 60 \\
Rata-rata & 84,44 & 78,51 \\
\hline
\end{tabular}

Dari tabel diatas dapat dilihat bahwa kedua kelas penelitian yang telah diberi post-test, maka diperoleh hasil ratarata yaitu, pembelajaran STAD adalah 84,44 sedangkan pada kelas NHT dperoleh nilai rata-rata adalah 78,51 Sebelum melakukan uji $\mathrm{t}$ harus periksa terlebih dahulu uji normalitas dan uji homogenitas varian, uji normalitas data skor post-test hasil belajar siswa menggunakan uji onesampel kolmogorov, berikut hasil rekapitulasi perhitungan hasil belajar siswa pada sub pokok sistem indra penglihatan pada manusia pada kelas STAD dan NHT. 1).Uji normalitas nilai post-test 
Tabel 6. Uji Normalitas Skor Post-Test Untuk Kelas Yang Menggunakan Model Pembelajaran Kooperatif Tipe STAD dan NHT

\begin{tabular}{|c|c|c|c|c|}
\hline \multicolumn{5}{|c|}{ Tests of Normality } \\
\hline \multirow{2}{*}{\multicolumn{2}{|c|}{ Model Pembelajaran }} & \multicolumn{3}{|c|}{ Kolmogorov-Smirnov } \\
\hline & & $\begin{array}{c}\text { Statis } \\
\text { tic }\end{array}$ & $\mathrm{df}$ & Sig. \\
\hline Hasil & STAD & 173 & 27 & ,038 \\
\hline Belajar & NHT & 287 & 27 & ,037 \\
\hline
\end{tabular}

Berdasarkan tabel di atas menunjukkan bahwa nilai pretest kemampuan awal siswa pada sub pokok sistem indra penglihatan pada manusia pada kelas STAD dan NHT berdistribusi normal, setelah diketahui normalitas data dilanjutkan dengan uji homogenitas varian, dengan menggunakan uji levana,hasil uji homogenitas varian adalah sebagai berikut:

\section{2). Uji Homogenitas nilai post-test}

Hasil homogenitas nilai post-test pada kedua sampel yaitu dengan pembelajaran STAD dan NHT dapat dilihat pada tabel dibawah ini, dan dari tabel dibawah ini dilihat signifikansinya lebih dari 0,05 sehingga kita ketahui bahwa data post-test kemampuan awal siswa yang menggunakan model pembelajaran STAD dan NHT mempunyai varians yang homogen.

3). Uji kemampuan awal

Setelah diketahui bahwa data posttest hasil belajar siswa ini berdistribusi normal dan homogen maka untuk melihat perbandingan perbedaan hasil belajar awal siswa dari kedua kelas maka dilakukan uji $t$ yang hasilnya sebagai berikut:

4). Menghitung nilai uji t atau uji hipotesis hasil belajar siswa

Tabel 7. Menghitung nilai uji $\mathrm{t}$ atau uji hipotesis Group Statistik

\begin{tabular}{ccccc}
\hline $\begin{array}{c}\text { Model } \\
\text { pembelajaran }\end{array}$ & $\mathrm{N}$ & Mean & Std.deviation & Std.Error mean \\
\hline STAD & 27 & 84,4444 & 11,20897 & 2,15717 \\
NHT & 27 & 78,5185 & 9,07393 & 1,74628
\end{tabular}

\section{Hipotesis nilai post-test}

Ho: $\mu 1=\mu 2$ (tidak ada perbedaan yang signifikan hasil belajar biologi Siswa antara yang menggunakan model pembelajaran Kooperatif tipe STAD dan yang menggunakan model pembelajaran NHT) Ho: $\mu 1 \neq \mu 2$ (ada perbedaan yang signifikan antara hasil belajar siswa Yang Menggunakan model pembelajaran kooperatif tipe STAD dan yang menggunakan model NHT pada mata Pelajaran biologi)

$$
\text { Berdasarkan analisis data }
$$
diperoleh nilai rata-rata hasil belajar biologi siswa kelas STAD setelah pembelajaran (post-test) adalah 84,44 dan sebelum pembelajaran (pre-test) adalah 55,92 dari nilai hasil rata-rata post-test dan pre-test didapat selisih rata-ratanya yaitu sebesar 28,52. Sedangkan nilai rata-rata 
hasil belajar siswa kelas NHT setelah pembelajaran (post-test) adalah 78,51 dan sebelum pembelajaran (pre-test) adalah 52,22 .

Dari hasil nilai rata-rata post-test dan pre-test didapat selisih rat-rata yaitu
26,29 sehingga nilai rata-rata hasil belajar siswa pada kelas STAD lebih besar dibandingkan dengan nilai-nilai hasil belajar siswa pada kelas NHT.

Tabel 7. Rata-rata hasil belajar siswa yang menggunakan tipe NHT dan yang menggunakan model STAD

Independent Samples Test

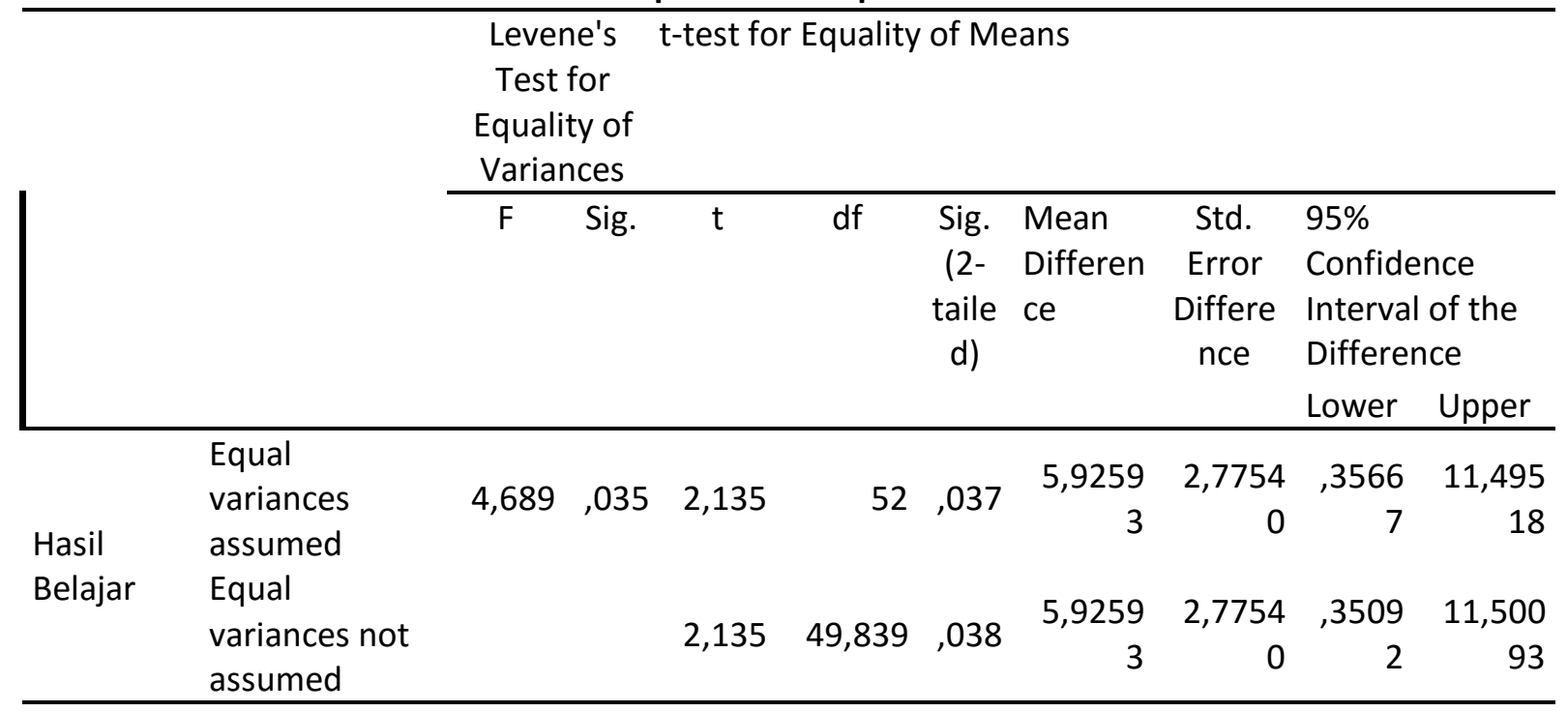

Rumus uji $t$ adalah untuk mengetahui perbandinagan perbedaan pengaruh pembelajaran yang tidak sama antara 2 kelompok pembelajaran.Rumus uji $\mathrm{t}$ digunakan karna dalam kelompok penelitian terdiri atas individu yang berbeda.

Dilihat pada hipotesis nilai pretest dan postest bahwa $\mathrm{Ho}: \mu 1=\mu 2$ menyatakan tidak ada perbedaan yang signifikan antara hasil belajar biologi Siswa antara yang menggunakan model pembelajaran kooperatif tipe STAD dan model pembelajaran tipe NHT,sedangkan Ho : $\mu 1 \neq \mu 2$ menyatakan bahwa ada perbedaan yang signifikan antara model pembelajaran kooperatif tipe STAD dan tipe NHT pada mata pelajaran.

Sehingga dapat disimpulkan ada perbedaan hasil belajar biologi siswa yang diajarkan melalui model pembelajaran kooperatif STAD dan model pembelajaran kooperatif tipe NHT,terjadi perbedaan tersebut salah satu nya adalah disebabkan adanya perbedaan perlakuan pada kedua kelas yaitu penerapan model pembelajaran kooperatif STAD pada kelas VIII 4 dan model pembelajaran kooperatif NHT pada kelas VIII 3

Perbedaan ini dikarnakan pada kelas VIII 4 diberikan model pembelajaran kooperatif tipe STAD, model pembelajaran tipe STAD ini membiasakan siswa untuk membangun pengetahuan sendiri sehingga kemampuan berpikirnya kreatip akan lebih terlatih dengan menyelesaikan masalah-masalah yang diberikan.Hal ini disebabkan pembelajaran kooperatif tipe STAD ini diawali dengan memberikan masalah-masalah yang ada, disajikan 
dalam LDS yang harus diselesaikan siswa untuk melatih membangun pengetahuannya sendiri. Dalam langkahlangkah tersebut siswa dilatih untuk berfikir menyelesaikan dengan cara sendiri, siswa yang dengan kemampuan rendah tetap dapat menyelesaikan permasalah tersebut dengan cara mereka sendiri dan pada model pembelajaran tipe STAD ini tim yang mendapat skor tertinggi mendapat penghargaan, kemudian siswa dikenai kuis tentang materi tersebut

$$
\text { Pada model pembelajaran }
$$

kooperatif tipe STAD terdapat komponen kerja tim. Kerja tim tersebut merupakan ciri terpenting dari STAD, pembelajaran kooperatif tipe STAD ditandai dengan menyampaikan tujuan pembelajaran diberikan pre-test untuk mengetahui kemampuan awal siswa,menyampaikan materi,siswa dibagi menjadi menjadi beberapa kelompok heterogen dalam satu kelompok terdiri dari 4-5 siswa kemudian diberikan LDS. Siswa mempersentasikan hasil diskusinya di depan kelas. siswa diberikan post test untuk mengetahui pemahaman materi yang telah diajarkan. Dan memberiak penghargaan sehingga kelompok siswa akan meningkat prestasi akademiknya.

Pada model pembelajaran kooperatif tipe NHT ini para siswa lebih dituntut berpikir bersama untuk menggambarkan dan menyakinkan bahwa tiap orang mengetahui jawabaan tersebut, pada pembelajaran ini hampir sama dengan pembelajarn kooperatif tipe STAD,guru menyampaikan terlebih dahulu tujuan pembelajaran kemudian diberikan pre-test untuk mengetahui kemampuan awal siswa, menyampaikan materi.

Rendahnya hasil yang di dapat siswa dalam pembelajaran model tipe NHT dibandingkan dengan pembelajaran kooperatif tipe STAD dikarnakan tidak semua siswa anggota kelompok dipanggil oleh guru dan terjadinya kegaduhan di dalam kelas. Dari hasil belajar kedua kelas eksperimen terjadi peningkatan hasil belajar sebagai akibat perlakuan yang diberikan berupa lingkungan belajar Cooperatif Learning.

Menurut Slavin (1995) dalam Trinto (2007) mengemukakan dua alasan mengapa pembelajaran kooperatif di anjurkan dua ahli pendidikan untuk digunakan, pertama beberapa hasil penelitian membuktikan bahwa penggunaan pembelajarn kooperatif dapat meningkatkan prestasi belajar siswa sekaligus dapat meningkatkan kemampuan hubungan sosial, menumbuhkan sikaf menerima diri dan orang lain. kedua, pembelajaran koperatif dapat merealisasikan kebutuhan siswa untuk berpikir, memecahkan masalah, dan mengintegrasiakan pengetahuan dalam keterampilan.

Berdasarkan penelitian yang telah dilakukan didapat kelebihan dalam pembelajaran kooperatif tipe STAD :

1) Siswa bekerja sama dalam mencapaikan tujuan pembelajarn.

2) Siswa aktif dalam membantu dan memotivasi semangat untuk berhasil bersama.

3) Interaksi antar siswa seiring dengan peningkatan kemampuan mereka dalam berpendapat.

Sedangkan kekurangannnya adalah membutuhkan waktu yang telah lama untuk siswa sehingga sulit mencapai kurikulum,siswa berprestasi tinggi akan mengarah pada kekecewaan karna peran anggota yang pandai lebih dominan.Sedangkan kelebihan dari model pembelajaran kooperatif tipe NHT adalah:

1) Setiap siswa menjadi siap semua

2) Dapat melakukan diskusi dengan sungguh-sungguh

3) Siswa yang pandai dapat mengajari siswa yang kurang pandai 
Kelemahan dalam model pembelajaran tipe NHT:

1) Kemungkinan nomor yang dipanggil akan dipanggil oleh guru lagi

2) Tidak semua anggota kelompok dipanggil oleh guru

3) Kendala teknis, misalnya masalah tempat duduk sulit atau kurang mendukung disetiap kegiatan kelompok.

Penigkatan hasil belajar pada kedua kelas berbeda secara signifikan sehingga dapat dikatakan bahwa pembelajarn antara model kooperatif tipe STAD dan model pembelajarn kooperatif tipe NHT ini pada pokok bahasan sistem indra penglihatan pada manusia terdapat perbedaan sgnifikan efektifitas model STAD dan NHT diamna model STAD lebih efektif dari kooperatif tipe NHT peserta didik didorong untuk menyelidiki masalh untuk mencari penjelasan dari masalah yang ada, menggali dan memperdalam cara mereka berpikir dengan menggunakan alternatif berpikir dan menganalisis data.

Peserta didik akan memperoleh informasi dengan penemuan-penemuan yang diperoleh sendiri dari pengalaman belajar yang yang telah mereka lakukan bersama kelompoknya,baik pada aspek kecepatan pemahaman siswa terhadap pelajaran dan hasil belar siswa,artinya tidak semua metode dapat digunakan dalam setiap pokok bahasan materi.

Dari proses pembelajaran yang telah dilakukan, diperoleh peningkatan hasil belajar siswa yang dapat dilihat bahwa hasil belajar tersebut dapat diperoleh siswa karna dapat memahami konsep materi yang dipelajari selama berada didalam tim kerja.

\section{KESIMPULAN}

Berdasarkan hasil penelitian tentang perbedaan hasil belajar siswa yang menggunakan model STAD dan NHT dapat disimpulkan bahwa: Pembelajaran kooperatif tipe STAD dapat meningkatkan hasil belajar biologi dibandingkan pembelajaran NHT dengan skor rata-rata dikelas STAD yaitu 84,44 sedangkan skor rata-rata NHT yaitu 78,51 dan terdapat perbedaan yang sangat signifikan pada hasil belajar dimana pada model pembelajaran STAD lebih tinggi dibandingkan pada model pembelajaran NHT.

\section{DAFTAR PUSTAKA}

Arikunto, S., Suhardjono., \& Supardi. (2012). Penelitian tindakan Kelas. Jakarta: PT Bumi Aksara.

Dimyati \& Mudjiono. (2013). Belajar dan Pembelajaran. Jakarta: Rineka Cipta.

Irwandi. (2010). Strategi Pembelajaran berbasis Kontekstual. UMB Press. Bengkulu

Hamalik, O. (2008). Kurikulum dan Pembelajaran. Jakarta: Bumi Aksara

Hamdani. (2011). Strategi Belajar Mengajar. Bandung : PT Pustaka Setia

Ibis, F. (2008). Macromedia Flash Animation Dan Cartoonin.

Kunandar. (2008). Penelitian Tindakan Kelas Sebagai Pengembang profesi Guru:PT Rajagrafindo Persada

Robert E. S. (2008). Cooperative Learning : Penerbit Nusa Media.

Sudijono, A. (2010). Pengantar Statistik Pendidikan. Jakarta :PT Raja Grafindo Persada

Trianto. (2010). Model Pembelajaran terpadu. Jakarta : PT Bumiaksara

Tirtarahadja, U. (2008). Pengantar pendidikan. Jakarta: PT Rineka Cipta 